\title{
アルゴンレーザーの形成・皮膚科領域への応用
}

\section{The Indication of the Argon Laser in the Fields of Plastic \& Reconstructive Surgery and Dermatology}

\author{
人城俊与 \\ Toshio Ohshiro, M.D.
}

大城䚲成外科

Ohshiro Clinic of Plastic \& Reconstructive Surgery

\section{SPECIFIC CHARACTERISTICS OF ARGON LASER IN THE TREATMENT OF NAEVI.}

In Table I, the characteristics of the argon laser and its therapeutic qualities can be seen. The argon laser is a continuous wave mode gas laser, operating in the visible light spectrum

Table 1: Argon Laser and Argon Laser Treatment Characteristics.

\begin{tabular}{|c|c|c|c|}
\hline Type of Laser & Gas & $\begin{array}{l}\text { Homogeneity of } \\
\text { Colour Tone: }\end{array}$ & Insufficient \\
\hline & Argon (Ar) & & \\
\hline Exposure & $\begin{array}{l}\text { Continuous Wave or } \\
\text { Switched }\end{array}$ & $\begin{array}{l}\text { Anesthetic (Local or } \\
\text { General): }\end{array}$ & Occasionally \\
\hline Wavelength (nm) & $488.0-514.5$ & Handling: & Easy \\
\hline Irradiation Time (sec.) & $0.05-\mathrm{C} / \mathrm{W}$ & Delicate Treatment: & Adequate \\
\hline Output Power & $0-3.0$ Watts & $\begin{array}{l}\text { Treatment for Irregular } \\
\text { Configuration: }\end{array}$ & Adequate \\
\hline $\begin{array}{l}\text { Diameter of Irradiated } \\
\text { Area }(\mathrm{mm})\end{array}$ & $1-2$ & Histological Selectivity: & Small \\
\hline Fibre Optic & Used & Radiant Heat Effect: & Small \\
\hline Repetition Rate (min.) & $\begin{array}{l}\text { Large } \\
\text { (over } 300 \text { p.p.min.) }\end{array}$ & $\begin{array}{l}\text { Conductive Heat } \\
\text { Effect: }\end{array}$ & Large. \\
\hline
\end{tabular}

from 488.0 to $514.5 \mathrm{~nm}$. It can be irradiated in either the continuous wave mode or with an optical switch to give a switched or burst wave. With the comparatively low output energy, the irradiated time must be correspondingly longer, and so some of the heat caused by the absorption of the laser beam is transferred to surrounding normal skin cells and tissue in conductive heat. Therefore, compared with the ultra-short acting ruby laser, the argon laser gives only a relatively histologically selective treatment. However, we can also use this conductive 
heat effect to treat the deeper layers of the skin. However, there is the serious problem of hypertrophic scarring to be considered, and so the argon laser must be irradiated in the "spotty" or "lineal" manner, which will be explained in detail later. In order to get a good result, reepithelisation of the wound must occur from the surrounding skin and the skin appendages in the wound.

In argon laser treatment, the beam is carried from the oscillator to the handpiece by means of a fibre optic, and is therefore easy to handle. The irradiated area is $2 \mathrm{~mm}$ in diameter, and the power output is relatively low. Because of these characteristics, we can use the argon laser for curved or irregularly shaped areas of the body, for delicate treatment such as between the hairs of the eyebrow, or for potentially dangerous treatment such as on the area around the eye or even on the margins of the eyelid, using in the latter cases a protective silver coated contact lens.

\section{TREATMENT METHODS USING ARGON LASER}

These treatment methods can be classified from the shape of the irradiated area.

a) Treatment in the "Spotty" manner ("Leopard" method)

Some types of naevi are composed of minute spots of pigment close together. If all the lesion is treated at the one time, the area might not be successfully reepithelised from the surrounding normal skin and the skin appendages in the treated area: the intact skin condition will not be achieved. If a wound heals so that no colour, configurational, functional or textural irregularities can be seen from a microscopic examination, I refer to this as the "intact skin condition". Thus in this treatment method small isolated spots of pigment are treated, leaving surrounding areas of untreated lesion so that reepithelisation can take place, giving the intact skin condition. I refer to this as the "Leopard" treatment method illustrated in Fig. 1. After reepithelisation of the wound has taken place, the surrounding untreated areas are irradiated in the same way, till the lesion is completely treated. We can also use this method in treatment modification

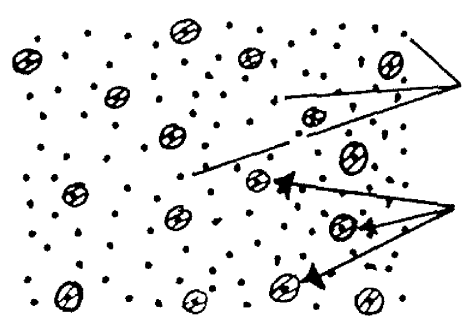

Fig. 1: The Leopard Treatment Method
Untreated Pigment

Spots after Laser Irradiation after another treatment, and it is suitable for use near the eye.

b) Treatment in the Lineal manner

i) Single Line method

From experience gained in my clinic, I have found that marginal reepithelisation is $1.5 \mathrm{~mm}$, thus in the case of a linear treated area of $3 \mathrm{~mm}$ in width, full reepithelisation can easily take place from the wound margins. If a lentigo has a diameter of $5 \mathrm{~mm}$, for example, then a line following the wrinkle lines of the area is irradiated across the diameter of the lesion. 
After reepithelisation, usually one month, the two remaining areas can be treated. This is shown diagrammatically in Fig. 2.

ii) The "Zebra" method

If the naevus extends over a larger area, we use the lineal manner in alternate stripes of treated and untreated areas, so that the whole treatment area appears "Zebra"-like. This is the "Zebra" method. The lines must foliow the natural wrinkle lines of the body. There are many

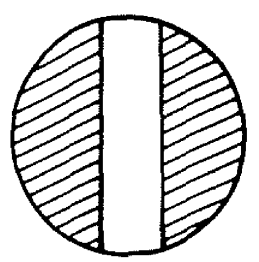

Fig. 2: Single Lineal Method for Lentigo variations in the ratio between the treated and untreated stripe size. The treatment ratios are $1: 1,2: 1,2: 2$, and so on, the exact ratio determined by the skin characteristics of each patient. Even on one patient, the skin has different characteristics site by site, so the ratio must be changed accordingly. The argon laser beam gives an irradiated area of $2 \mathrm{~mm}$ in diameter and Fig. 3 shows the $1: 1$ ( $2 \mathrm{~mm}$ treated-2mm untreated) and $2: 1$ ( $4 \mathrm{~mm}$ treated-2mm untreated) ratios.

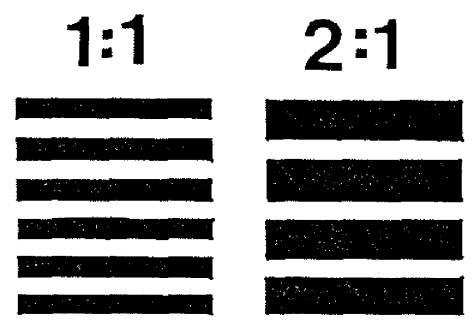

Fig. 3: Ratios in Zebra Method

\section{CLASSIFICATION OF TREATMENT FROM PHOTOBIOLOGICAL REACTION}

When a stimulus is given to the human body, a reaction occurs. Damage is a form of stimulus, and the repairing reaction of the body to this damage/stimulus can be used to treat naevi. Therefore we can classify treatment from the point of view of bodily reaction.

\section{a) Coagulation Treatment Method}

When the argon laser is irradiated onto haemangioma simplex, the low output energy of the argon laser cannot coagulate the blood flowing through the blood vessels because of the speed of the blood flow, which has a cooling effect thus preventing coagulation. When we want to irradiate the argon laser on the distal parts of the extremities, the blood flow must be stopped using a tourniquet. Then coagulation can be obtained with the argon laser as the blood flow has been stopped. This I refer to as the coagulation method.

b) Vapourisation Method

When the visible light laser beam is irradiated onto a naevus, the abnormal coloured naevus cells or materials absorb more of the laser light beam than the normal cells and tissues. The temperature of the abnormal cells or materials is raised by the conversion of the absorbed light into heat. As cells contain a high percentage of water, the temperature can never exceed $100^{\circ} \mathrm{C}$, and thus the heat easily causes vapourisation in the darker cells or materials. By using this vapourisation we can treat naevi; the treatment is subdivided into two methods, vacunlation and carbonisation. 
i) Epithelial peeling with the vapourisation and vacuolation in the epidermo-dermal junction only.

ii) Micro-vacuolation in the tissue. This method can be applied to cells, tissue and materials. Electron microscopic specimens show clearly the microvacuolation in cells and tissue after argon laser irradiation, therefore we can use this as a stimulus to stimulate the body's healing reaction to reject, absorb or otherwise dispose of abnormal cells or materials. The vacuolation at $100^{\circ} \mathrm{C}$ has two destructive mechanisms, (a) the damage caused by the transfer of conductive heat, and (b) the dynamic destruction of the cells themselves.

iii) Carbonisation. This causes the direct destruction of cells, tissue, and materials. This method is limited to materials which can carbonise. In tattoo, for example, titanium is white, so it cannot absorb the laser light and therefore will not heat up. Ferrous oxide pigments further oxidise to a different colour, but they are not carbonised. In the case of successfully carbonised cells or materials, those in the superficial layer of the skin are removed in the crust, while those in the deeper layer are removed by the blood and lymphatic vessels, and excreted from the body. 
therapy is already well documented (7) (8). We combine sponge or gauze pressure using elastic bandages with our laser therapy. The results have been very favourable, the time course being shorter and the results better than with pressure therapy alone. Topical steroid ointment application and intradermal injection therapy are favoured by some surgeons. We have found that steroid therapy is contraindicated in our argon laser and pressure combined treatment method: the reason for this is not clear. We must apologize for the lack of histological evidence in the form of photomicrography and scanning electron microscopy. At present, we are treating hypertrophic scars mostly as a result of previous laser therapy, and therefore we are unwilling at this early stage to take histological specimens. However, as our results continue to be favourable, in the near future we will offer some concrete evidence for the hypothetical explanations we have given here.

\section{CONCLUSION}

In the course of argon laser therapy for haemangioma simplex in which some hypertrophic scarring existed from a previous therapy, it was noticed that the laser was having good results on the hypertrophic problem. As a result, two cases are reported where the argon laser was applied only for the treatment of hypertrophic scarring. We suggest that the laser beam causes (a) a fairly immediate thermochemical reaction and (b) a later, longer term photochemical and photoenzymatic reaction. In addition to the laser, we use pressure therapy in the combination treatment method, but we have found steroids contraindicated. Further detailed microscopic and histological examinations are planned for the near future, to verify our theories.

\section{REFERENCES}

(1) Apfelberg DB, Maser RM and Lash $\mathrm{H}$ : Argon Laser Treatment of Decorative Tattoos: Brit. J. Plas. Surg. 32; 141-144, 1979.

(2) Cosman B: Experience in the Argon Laser Therapy of Port Wine Stains; Plas. R. Surg. 45,$2 ; 119-127,1980$.

(3) Reid R. and Muller S: Tattoo Removal $\mathrm{By} \mathrm{CO}_{2}$ Laser Dermabrasion: Plas. R. Surg. 45, 4: 717-728, 1980.

(4) Ohshiro T: The Side Effects from "Laser Treatment for Nevi" Tokyo, Medical Laser Company Ltd. (MEL) 1980.

(5) Ohshiro T: Argon Laser Treatment from op. cit. p. 60.

(6) Oshhiro T: The Medical Use of Laser from, op. cit. p. 17.

(7) Fujimori $R$, Hiramoto $M$ and Ofugi $S$ : Sponge fixation method for treatment of early scars: Plas. R. Surg. 42: 322, 1968.

(8) Crikelair GF, Ju DMC and Cosman B: Scars and Keloids from "Reconstructive Plastic Surgery" ed. Converse JM: Philadelphia, W.B. Saunders Company 413-441, 1977. 